\title{
Deposition of copper, iron, manganese and zinc in the empty body of growing lambs of the breed German Merino Landsheep
}

\author{
G. Bellof ${ }^{1 \dagger}$ and J. Pallauf ${ }^{2}$ \\ ${ }^{1}$ Section Animal Nutrition, Weihenstephan University of Applied Sciences, D-85350 Freising, Germany; ${ }^{2}$ Institute of Animal Nutrition and Nutrition Physiology, \\ Justus Liebig University Giessen, D-35392 Giessen, Germany
}

(Received 25 July 2006; Accepted 7 March 2007)

A growth experiment with 108 lambs (breed: German Merino Landsheep) was carried out to examine the effect of gender, body weight (BW) and feeding intensity on the deposition of $\mathrm{Fe}, \mathrm{Zn}, \mathrm{Cu}$ and $\mathrm{Mn}$ in the empty body (whole animal minus contents of the gastrointestinal tract and bladder). The lambs (50\% female and 50\% male animals) were fed at three feeding levels ('low', 'medium' and 'high' by varying daily amounts of concentrate and hay) and slaughtered at different final BWs $(30,45$ or $55 \mathrm{~kg})$. Six male and six female animals were killed at a BW of $18 \mathrm{~kg}$ representing the animals' BW at the beginning of the comparative slaughter experiment. There were significant main effects for the treatments growth rate and final weight on the daily rate of accretion of the trace elements examined. Feeding intensity had a marked influence on the accretion rate for Fe $(\mathbb{P}<0.001), Z n(P<0.001), C u(P<0.001)$ and $\mathrm{Mn}(\mathbb{P}=0.003)$. With increasing feeding intensity (low, medium, high) the daily deposition of these trace elements increased (4.4, 5.2, $6.6 \mathrm{mg} /$ day for $\mathrm{Fe} ; 4.9,5.5,6.9 \mathrm{mg} /$ day for $\mathrm{Zn} ; 0.20,0.36$, $0.44 \mathrm{mg} /$ day for $\mathrm{Cu} ; 0.14,0.16,0.21 \mathrm{mg} /$ day for Mn). Heavier final BW led to increased daily retention of $\mathrm{Zn}(\mathrm{P}<0.001)$ and $\mathrm{Mn}(\mathrm{P}=0.002)$. Gender had a marked influence only on the accretion rate for $\mathrm{Zn}(\mathrm{P}<0.001)$. Ram lambs had a higher daily deposition of this element than female lambs. Related to $1000 \mathrm{~g}$ empty body gain, the following concentrations were found for the trace elements examined: Fe $26.1 \mathrm{mg}, \mathrm{Zn} 30.0 \mathrm{mg}$, Cu $1.41 \mathrm{mg}$ and $\mathrm{Mn} 1.04 \mathrm{mg}$. A feeding influence was given for $\mathrm{Zn}$ $(\mathrm{P}<0.001)$ and $\mathrm{Cu}(\mathrm{P}=0.039)$. Feeding level low had higher $\mathrm{Zn}$ and lower $\mathrm{Cu}$ concentrations. Male animals showed less $\mathrm{Fe}$ $(\mathrm{P}<0.001)$ and $\mathrm{Zn}(\mathrm{P}=0.034)$ per $\mathrm{kg}$ empty body gain than females.

Keywords: copper, growth, iron, lambs, manganese, Merinolandschaf, zinc

\section{Introduction}

The correct estimation of the mineral requirements of growing sheep needs an exact knowledge of mineral deposition in the body. There are few references to the trace element contents in the body of growing lambs in the literature (e.g. Suttle, 1979; Agricultural Research Council (ARC), 1980; Wilkinson et al., 2003). Furthermore, most of these studies focus on the production of meat (e.g. Lin et al., 1989; Hoffman et al., 2003). The emphasis on breeding for the lamb meat has led to a shift in the deposition of nutrients in tissues as can be seen for lambs of the most important German sheep breed: German Merino Landsheep (Bellof et al., 2003a).

A systematic investigation of important influences such as gender, final BW and feeding intensity on a genotype of a current breed is not available. Therefore, the influence of

\footnotetext{
${ }^{\dagger}$ E-mail: gerhard.bellof@fh-weihenstephan.de
}

gender, final BW and feeding intensity on the accretion of the trace elements copper $(\mathrm{Cu})$, iron $(\mathrm{Fe})$, manganese $(\mathrm{Mn})$ and zinc ( $(\mathrm{n})$ in empty bodies was examined in an extensive study based on a growth experiment with lambs of the breed German Merino Landsheep.

\section{Material and methods}

The trial was carried out using a total of 108 lambs $(50 \%$ female and $50 \%$ male) of the genotype German Merino Landsheep. The age of all animals was known as well as whether reared as singletons or twins. The animals were kept at the Agricultural Training and Research Station of the University of Applied Sciences Weihenstephan and fattened at different feeding levels. The diet was given at the feeding levels 'low feeding intensity', 'medium feeding intensity' and 'high feeding intensity' by varying proportions of concentrate (Table 1) and hay in the daily ration. The feeding level 'high' corresponded to a concentrate-intensive diet, 
Bellof and Pallauf

Table 1 Composition of concentrate for lambs

\begin{tabular}{lc}
\hline \hline Ingredient & $\%$ \\
\hline Barley & 53.0 \\
Oats & 10.0 \\
Dried sugar-beet pulp & 15.0 \\
Soya-bean meal & 18.0 \\
Soya-bean oil & 1.0 \\
Pre-mix & \\
Calcium carbonate & 0.75 \\
Ammonium chloride & 2.0 \\
\hline \hline
\end{tabular}

${ }^{+}$Content per kg pre-mix: $160 \mathrm{~g} \mathrm{Ca}, 50 \mathrm{~g} \mathrm{P}, 75 \mathrm{~g} \mathrm{Na}, 22 \mathrm{~g} \mathrm{Mg}, 1200 \mathrm{mg} \mathrm{Fe}$, $9 \mathrm{mg} \mathrm{Cu}, 2650 \mathrm{mg} \mathrm{Zn}, 1160 \mathrm{mg} \mathrm{Mn}, 10 \mathrm{mg} \mathrm{Co}, 37 \mathrm{mg} \mathrm{Se}, 30 \mathrm{mg} \mathrm{I}, 475000$ IU Vitamin A, 5800 IU Vitamin D3, $145 \mathrm{mg}$ Vitamin E.

Table 2 Content of crude protein, metabolisable energy (ME), ash and trace elements in concentrate and hay for lambs (mean \pm s.d.)

\begin{tabular}{lccccc}
\hline \hline & \multicolumn{2}{c}{ Concentrate } & & \multicolumn{2}{c}{ Hay } \\
\cline { 2 - 3 } \cline { 6 - 7 } Item & Mean & s.d. & & Mean & s.d. \\
\hline Dry matter (DM, \%) & 88.5 & 0.38 & & 89.3 & 2.03 \\
Crude protein (g/kg DM) & 179 & 4.4 & & 90 & 7.2 \\
ME (MJ/kg DM) & 12.35 & 0.09 & & 9.15 & 0.27 \\
Ash (g/kg DM) & 67.5 & 3.12 & & 73.6 & 4.66 \\
Cu (mg/kg DM) & 6.57 & 1.07 & & 6.09 & 0.90 \\
Fe (mg/kg DM) & 273.4 & 48.1 & & 188.7 & 52.4 \\
Mn (mg/kg DM) & 54.77 & 5.97 & & 70.60 & 6.90 \\
Zn (mg/kg DM) & 70.36 & 12.28 & & 21.72 & 3.64 \\
\hline \hline
\end{tabular}

${ }^{\dagger}$ Determined from the digestible crude nutrients using equations for estimation of ME (Society of Nutrition Physiology, 1995).

whereas the level 'low' corresponded to slow growth diet. The content of nutrients and metabolisable energy (ME) in the concentrate and hay is given in Table 2. The ME concentration in the dietary dry matter (DM) of the ration varied between 11.5 (low) and 12.1 MJ ME per kg DM (high). Within the feeding levels, there was no difference in the feeding schedule for gender. By using special demandfeeding stations, it was possible to record exactly the daily feed intake of each animal despite keeping it in groups (separated according to gender). Four different final BWs (slaughter weights) were selected: $18,30,45$ and $55 \mathrm{~kg}$. There was no differentiation in the feeding intensity for the first weight level of $18 \mathrm{~kg}$. A detailed description of the experimental design, as well as the results of fattening and slaughter performance, has been reported elsewhere (Bellof et al., 2003b).

The slaughtering of the sheep was carried out at the experimental slaughterhouse of the Bavarian State Research Centre for Agriculture (LfL), Grub. After a cooling period of $26 \mathrm{~h}$ at $2{ }^{\circ} \mathrm{C}$, the cold carcass weight as well as the half carcass weight, was determined. The left half of the carcass was cut according to the pattern of the German Society of Agriculture (DLG) (Scheper and Scholz, 1985). Each piece was then divided into muscle tissue, fat tissue and bones/sinews (Bellof et al., 2003c). In total, the data from 101 carcasses (50 male and 51 female animals) were collected and analysed (seven animals did not reach the final stage). A detailed description of the dissection and composition of the carcass over the growing period was published earlier (Bellof et al., 2003c; Bellof and Pallauf, 2004).

After the carcasses had been dissected, the samples were prepared. The minced and homogenised muscle, and fat tissues of the different pieces were blended to an aliquot sample. Part of the frozen samples was analysed for crude ash and minerals. In the same way, samples of the bone/ sinew tissues and of the 'residues' (including empty digestive tract and bladder, the internal organs, hide, flesh taken from head and feet) of every slaughtered animal were used for analysis of the mineral matter. The samples of fat tissue of each animal were pooled for every subgroup (gender, BW and feeding level). For blood and wool, the analysis of minerals was confined to similarly pooled samples. All samples intended for mineral analysis were freeze-dried.

The feed used in the trial was analysed for its content of trace elements (Table 2). The feed samples were collected on a weekly basis during the trial and were pooled (monthly periods) before the samples were analysed. Based on the recorded feed intake of each animal, the mean daily intake of trace elements could be calculated for every animal (Table 3).

The trace element analyses were carried out at the Institute of Animal Nutrition and Nutrition Physiology at the Justus Liebig University, Giessen. The samples were prepared as follows: about $3 \mathrm{~g}$ of each homogenised sample material (fat tissue, muscle tissue and bone tissue) were weighed exactly into quartz pans. In order to determine the remaining moisture, the samples were dried again $\left(3 \mathrm{~h}\right.$ at $105^{\circ} \mathrm{C}$ ). The ashing was carried out in a muffle furnace at $450^{\circ} \mathrm{C}$ over a 12 -h period. The ash was dissolved in $3 \mathrm{~mol} / / \mathrm{HNO}_{3}$ suprapur and heated for $10 \mathrm{~min}$ in a waterbath. Afterwards, the ash solution was filtered into a measuring flask with hot bi-distilled water. The residue on the filter underwent further ashing $\left(450^{\circ} \mathrm{C}\right)$ for another $12 \mathrm{~h}$ and was filtered again. The final acid concentration in the solution was $0.3 \mathrm{~mol} / \mathrm{l} \mathrm{HNO}_{3}$.

The trace elements were measured with ICP-AES by Unicam PU701 (now: Thermo Electron $\mathrm{GmbH}$, Dreieich, Germany), power: 1000 W, plasma: radial observation, sprayer: Hildebrand-Grid, sprayer pressure: 34-40 p.s.i., argon-cooling gas: $11 \mathrm{l} / \mathrm{min}$, flow of the sample: $1 \mathrm{ml} / \mathrm{min}$, with the emission wavelength specific for each element.

The measurement of the $\mathrm{Cu}$ contents in the fat tissues led to results below the detection limit of $0.05 \mathrm{mg} / \mathrm{l}$ measure solvent. In the meat, bone and fat samples, the measurement of $\mathrm{Mn}$ led to results below the detection limit of $0.05 \mathrm{mg} / \mathrm{l}$. Therefore, a re-measurement of Mn was carried out for the bone samples using an atomic absorption spectrometer (graphite furnace AAS by PerkinElmer (PE $5100 \mathrm{Z}$ ); details of the instrument: wave length: $279.5 \mathrm{~nm}$; gap width: $0.2 \mathrm{~nm}$; lamp current: $20 \mathrm{~mA}$; base 
correction: Zeeman; cuvette: not coated; injection capacity: $20 \mu \mathrm{l}$; modifier: none; integration: area; drying: two-stage $\left(90^{\circ} \mathrm{C}\right.$ and $\left.120^{\circ} \mathrm{C}\right)$; ashing: two-stage $\left(500^{\circ} \mathrm{C}\right.$ and $\left.900^{\circ} \mathrm{C}\right)$; atomisation: $2200^{\circ} \mathrm{C}$ ). The calibration took place at a concentration of $1-10 \mu \mathrm{g} / \mathrm{l}$. $\mathrm{Cu}$ in bones was analysed by flame AAS (Unicam PU 9400 (now: Thermo Electron GmbH, Dreieich, Germany, measuring principle: flame: airacetylene; wavelength: $324.8 \mathrm{~nm}$; gap width: $0.5 \mathrm{~nm}$ ). For quality control of the trace element analysis, certified bovine liver (NIST bovine liver 1577 b) was used. The recovery rate measured was $107 \%$ for $\mathrm{Fe}, 102 \%$ for $\mathrm{Cu}$, $103 \%$ for $\mathrm{Mn}$ and $98 \%$ for $\mathrm{Zn}$.

The total of $\mathrm{Cu}, \mathrm{Fe}, \mathrm{Mn}$ and $\mathrm{Zn}$ contents in the body tissues, muscle, fat and bone (Bellof et al., 2007) and in the residues, as well as in blood and wool, were calculated for each animal ('empty body' = slaughtered animal minus content of gastrointestinal tract and bladder).

The statistical analysis of the individual data was conducted using the GLM procedure of the statistical program SAS (Statistical Analysis Systems Institute, 1988).

$$
y_{i j k l}=\mu+\alpha_{i}+\beta_{j}+\gamma_{k}+\varepsilon_{i j k l}
$$

where $y$ represents trace elements (daily intake (mg/day), deposition in empty body $(\mathrm{mg} / \mathrm{kg})$ or daily retention $(\mathrm{mg} /$ day)); $\alpha$ the feeding level; $\beta$ the sex; and $\gamma$ the BW.

The data showed a normal distribution. Significance tests for fixed effects were carried out using the F-test. Differences between the subgroups were tested for significance using the $t$-test. Since no significant interactions were determined, results of three-factorial analysis of variance (feeding level, sex, BW) are shown in the tables.

On the basis of the deposition of the determined trace elements, the body composition during the course of growth was calculated with allometric estimated equations according to the ARC (1980):

$$
\log _{10} y=a+b \log _{10} x
$$

where $y$ is the deposition of trace elements [in empty body, $(\mathrm{mg} / \mathrm{kg})]$ and $x$ the empty BW $(\mathrm{kg})$.

Equation (2) was fitted to representative values for the mineral body composition of German Merino Landsheep of both genders.

\section{Results}

Increasing feeding intensity (low, medium, high) led to a marked daily increase in BW gain (BWG; 208, 253 and $305 \mathrm{~g}$ ). At the same time there was a lowered energy intake per kg BWG (50.9, 47.9, 45.9 MJ ME per kg). Increasing BW $(30,45$ and $55 \mathrm{~kg})$ led to a decreased energy efficiency ratio (41.2, 50.0, 53.5 MJ ME per kg). The different feeding intensities and the fixed final fattening weights led to a considerable differentiation in the actual age. While ram lambs at feeding intensity 'high' were only 92 days old on reaching the final fattening weight of $30 \mathrm{~kg}$, the males at feeding level 'low' reached the final live weight of $55 \mathrm{~kg}$ at 
Bellof and Pallauf

Table 4 Parameters for estimation ${ }^{\dagger}$ of the concentration of trace elements in the empty body of growing sheep of the genotype German Merino Landsheep

\begin{tabular}{|c|c|c|c|c|}
\hline Element & Group & $b$ (土s.e.) & a (土s.e.) & Coefficient of determination $\left(R^{2}\right)$ \\
\hline \multirow[t]{3}{*}{$\mathrm{Fe}$} & All & $-0.13116 \pm 0.03542$ & $1.66938 \pm 0.05216$ & 0.1217 \\
\hline & Male & $-0.22188 \pm 0.04545$ & $1.81280 \pm 0.06684$ & 0.3318 \\
\hline & Female & $-0.04289 \pm 0.05011$ & $1.52938 \pm 0.07392$ & 0.0147 \\
\hline \multirow[t]{3}{*}{$\mathrm{Zn}$} & All & $0.10729 \pm 0.01750$ & $1.27695 \pm 0.02577$ & 0.2753 \\
\hline & Male & $0.09137 \pm 0.02342$ & $1.29667 \pm 0.03444$ & 0.2408 \\
\hline & Female & $0.12183 \pm 0.02580$ & $1.25911 \pm 0.03806$ & 0.3127 \\
\hline \multirow[t]{3}{*}{$\mathrm{Cu}$} & All & $-0.22299 \pm 0.05901$ & $0.57261 \pm 0.08692$ & 0.1261 \\
\hline & Male & $-0.36285 \pm 0.08488$ & $0.79203 \pm 0.12483$ & 0.2758 \\
\hline & Female & $-0.08720 \pm 0.07677$ & $0.35886 \pm 0.11325$ & 0.0257 \\
\hline \multirow[t]{3}{*}{$\mathrm{Mn}$} & All & $0.37647 \pm 0.06197$ & $-0.74187 \pm 0.35907$ & 0.2597 \\
\hline & Male & $0.20092 \pm 0.08147$ & $-0.48274 \pm 0.11983$ & 0.0950 \\
\hline & Female & $0.54410 \pm 0.08736$ & $-0.99007 \pm 0.12887$ & 0.4482 \\
\hline
\end{tabular}

${ }^{+} \log _{10} y=a+b \log _{10} x$.

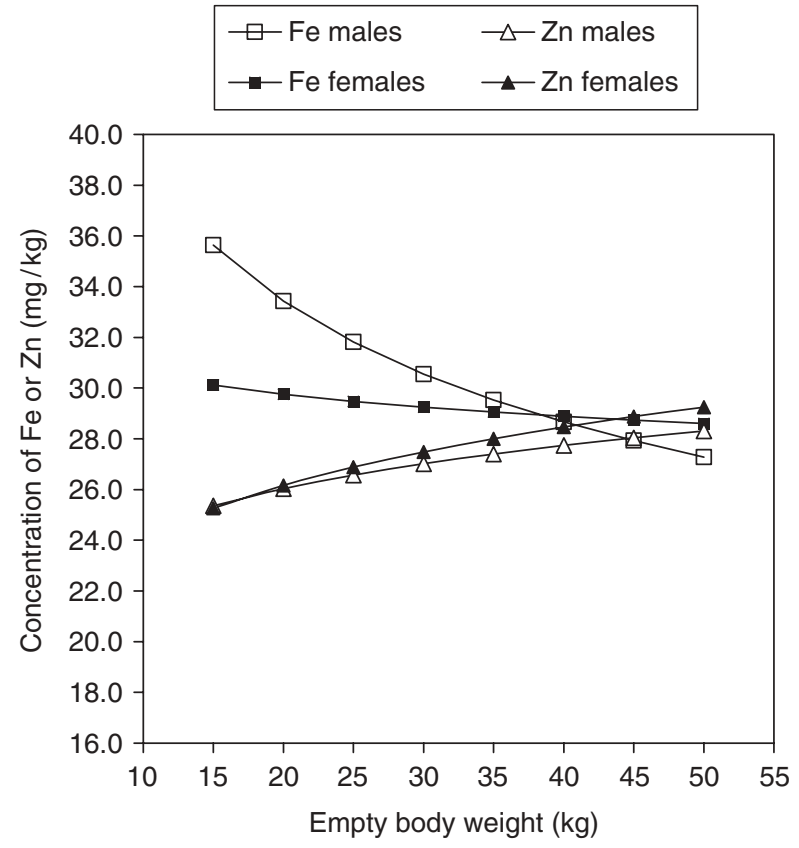

Figure 1 Content of iron (Fe) and zinc ( $\mathrm{Zn})$ in the empty body of lambs of the genotype German Merino Landsheep.

an average age of 209 days. The female animals were 21 and 37 days older than males at these feeding intensities.

The analysed contents of ash and trace elements in the feedstuffs are listed in Table 2. The amounts of trace elements corresponded to the amounts in standard commercial concentrate mixtures.

The trace element intake during the different fattening periods is shown in Table 3. In accordance with the feeding plan, the average daily intake of the trace elements Fe, Zn and $\mathrm{Cu}$ increased significantly $(P<0.001)$ with increasing amount of concentrate. The intake of $\mathrm{Fe}, \mathrm{Zn}, \mathrm{Cu}$ and $\mathrm{Mn}$ also increased with higher BW $(P<0.001)$. As in the intake of concentrate and hay (Table 3$)$, there were only minor differences in the intake of trace elements between male and female animals in the course of growth.

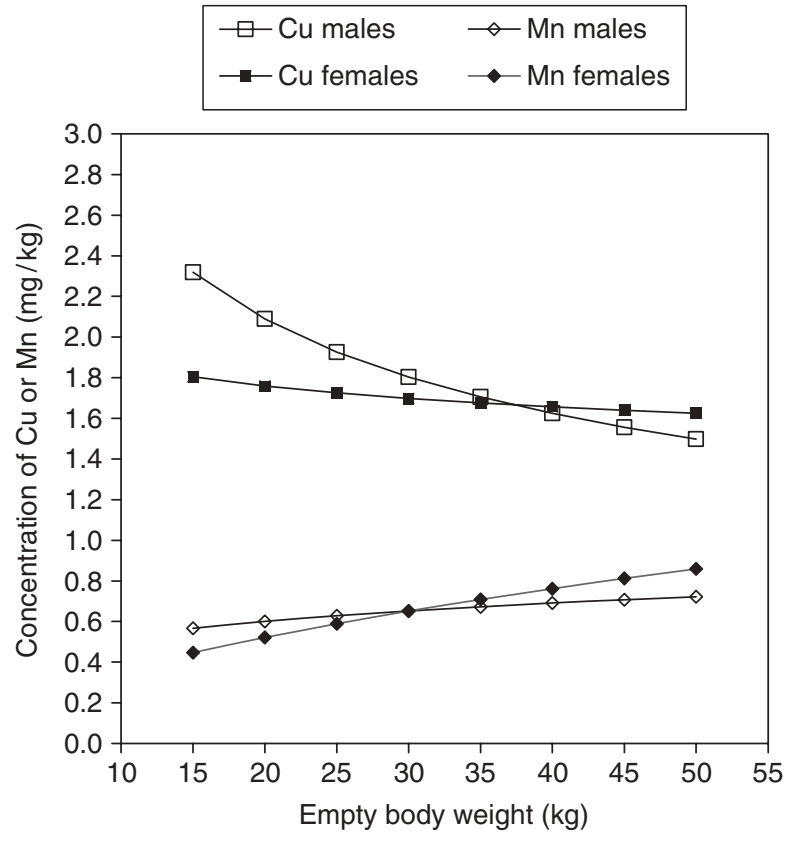

Figure 2 Content of copper (Cu) and manganese (Mn) in the empty body of lambs of the genotype German Merino Landsheep.

The estimated equations (2) derived for the deposition of trace elements in the empty body are shown in Table 4. The graphics derived from the equations are shown for both genders in Figures 1 (Fe and $\mathrm{Zn}$ ) and 2 ( $\mathrm{Cu}$ and $\mathrm{Mn}$ ). While a continuous decrease during the growing period was detected for $\mathrm{Fe}$, the $\mathrm{Zn}$ content increased moderately. Differences due to gender could be seen only for the content of Fe. With males, the values per kg empty BW decreased more sharply than with female lambs (Figure 1). The content of $\mathrm{Cu}$ was reduced in the growing period for both genders. As in the case of Fe the decrease was more marked for ram lambs than for females (Figure 2). The $\mathrm{Mn}$ content increased with higher empty BW for both genders.

The mean deposition of trace elements per $\mathrm{kg}$ gain of empty BW is given in Table 5 . The feeding intensity had an 
influence on the deposition of $\mathrm{Zn}(P<0.001)$ and $\mathrm{Cu}$ $(P=0.039)$. Lambs fed at the low level had higher $\mathrm{Zn}$ and lower $\mathrm{Cu}$ concentrations. A significant influence of gender could be proved only for the elements Fe and $\mathrm{Zn}$. Male animals showed less Fe $(P<0.001)$ and $\mathrm{Zn}(P=0.034)$ per $\mathrm{kg}$ empty BWG than females. The observed BW ranges influenced only the deposition of $\mathrm{Zn}(P<0.001)$ and $\mathrm{Mn}$ $(P<0.001)$. Both elements increased with higher final BW.

During the whole trial (18-55 kg BW), the lambs retained an average $26.1 \mathrm{mg} \mathrm{Fe}$ and $30.0 \mathrm{mg} \mathrm{Zn}$ per kg gain of empty BW. Females showed a higher deposition of Fe $(+8.2 \mathrm{mg} /$ $\mathrm{kg} ; P<0.001)$ and $\mathrm{Zn}(+1.3 \mathrm{mg} / \mathrm{kg} ; P=0.034)$ than ram lambs. With increasing feeding intensity the deposition of Zn diminished $(P<0.001)$.

The mean deposition of $\mathrm{Cu}(18-55 \mathrm{~kg} \mathrm{BW})$ amounted to $1.41 \mathrm{~g} / \mathrm{kg}$ of empty BWG (Table 5). The animals at the low feeding level showed a lower deposition of $\mathrm{Cu}$ than those at medium level $(P=0.015)$ and also a tendency at high levels $(P=0.073)$.

In the BW range $18-55 \mathrm{~kg}$, the lambs retained an average $1.04 \mathrm{mg} \mathrm{Mn}$ per $\mathrm{kg}$ of empty BWG. Female lambs tended to a slightly higher deposition of $\mathrm{Mn}(+0.21 \mathrm{mg} / \mathrm{kg}$; $P=0.087$ ).

The mean daily deposition of trace elements in the empty body is described in Table 6. As expected, the feeding intensity had an influence on the daily deposition of $\mathrm{Fe}$ $(P<0.001)$, Zn $(P<0.001)$, Cu $(P<0.001)$ and $\mathrm{Mn}$ $(P=0.003)$. With increased feeding intensity the daily retention of these elements increased. A significant influence of gender could be proved only for the deposition of Zn $(P<0.001)$. Male lambs showed a higher daily retention of $\mathrm{Zn}$. The different $\mathrm{BW}$ ranges, however, influenced only the daily deposition of $\mathrm{Zn}(P<0.001)$ and $\mathrm{Mn}(P=0.002)$. The deposition of both elements increased with higher final BW.

The mean daily deposition of $\mathrm{Fe}$ in lambs increased according to feeding intensity. Lambs with a 'high' energy supply showed a $50 \%$ higher $(P<0.001)$ daily deposition of Fe than animals with 'low' supply. Females had a tendency to a higher deposition of Fe than male lambs $(5.7 \mathrm{mg} /$ day v. $5.2 \mathrm{mg} /$ day; $P=0.191$ ).

The mean daily deposition of $\mathrm{Zn}$ in lambs amounted to $6.3 \mathrm{mg}$ during the growing period (18-55 $\mathrm{kg}$ BW) and increased significantly with increased feeding intensity. Animals at feeding level 'high' showed $41 \%$ higher $(P<0.001)$ daily deposition of $\mathrm{Zn}$ than those on the 'low' level. Ram lambs had a $0.7 \mathrm{mg} /$ day higher deposition of $\mathrm{Zn}$ than female lambs $(P<0.001)$.

The mean daily deposition of $\mathrm{Cu}$ amounted to $0.30 \mathrm{mg}$. With increasing feeding intensity, the deposition of $\mathrm{Cu}$ increased significantly. Lambs on the high feeding level showed a more than twice as high daily deposition of $\mathrm{Cu}$ than those on the low level $(P<0.001)$.

The mean daily deposition of $\mathrm{Mn}$ in lambs amounted to $0.21 \mathrm{mg} /$ day. With higher feeding intensity the deposition of $\mathrm{Mn}$ increased significantly. Lambs on the high feeding level showed a $67 \%$ higher daily deposition than those on low 


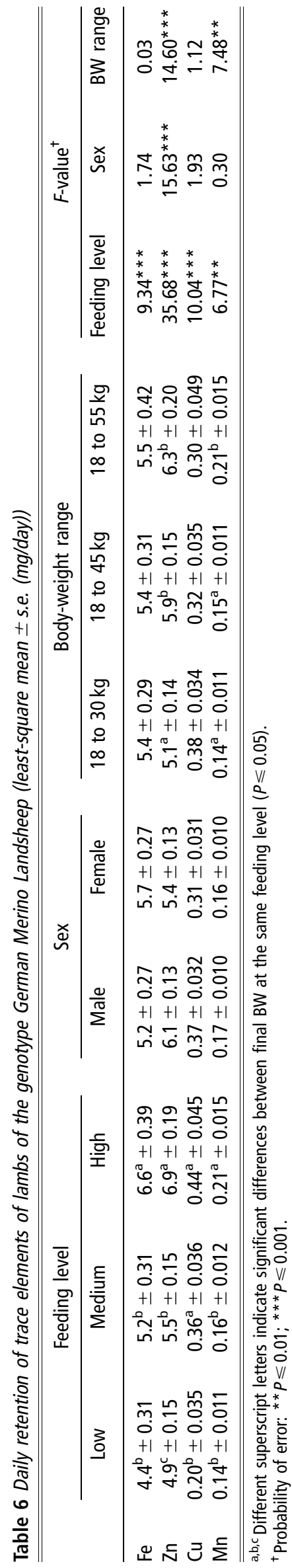

$(P<0.001)$. No differences due to gender were detected for daily deposition of $\mathrm{Mn}$.

The following retention (\% of intake) of ingested trace elements in the empty body (both genders, feeding level 'medium') was calculated: Fe 2.0, Zn 8.9, Cu 5.5 and Mn 0.27.

\section{Discussion}

An adequate supply of the trace elements $\mathrm{Fe}, \mathrm{Zn}, \mathrm{Cu}$ and $\mathrm{Mn}$ was ensured for all feeding levels of the lambs as a comparison with the recommendations of the National Research Council (NRC, 1985) in $\mathrm{mg} / \mathrm{kg}$ of diet DM (Fe 30-50, Zn 20-33, Cu 7-11, Mn 20-40) for sheep shows. An over-supply was present only for Fe. However, the upper limit of $500 \mathrm{mg}$ Fe per $\mathrm{kg}$ DM (NRC, 1985) was not reached even in the high concentrate groups $(273 \mathrm{mg} / \mathrm{kg} \mathrm{DM})$. The $\mathrm{Cu}$ intake reached the recommendations by the NRC (1985) at all feeding levels, but the recommendations given by the ARC (1980) with $1.8-5.1 \mathrm{mg} / \mathrm{kg}$ DM were slightly exceeded. According to the experimental design, there was no intended variation of trace element levels in the diet. Therefore, conclusions on the influence of varying trace element supply are not possible.

The trace element Fe in the empty body of lambs was found mainly in the bone tissue $(40 \%$ of the total $\mathrm{Fe}$, related to the empty BW (Bellof et al., 2007)). In addition, significant amounts of Fe could be determined in the residue $(19 \%)$, as well as in muscle tissue and blood $(15 \%$, respectively). For $Z n$, the following average distribution in the empty body was detected: muscle tissue $42 \%$, bone tissue $29 \%$, residue $13 \%$ and wool $13 \%$. More than $55 \%$ of the total Cu was found in the residue, mainly in the liver, while muscle tissue and wool were about equal, $17 \%$ and $16 \%$. In the bone tissue, about $11 \%$ of the total Cu was discovered. The element $\mathrm{Mn}$ was found mainly in the wool $(41 \%)$ and in the residue $(40 \%)$, whereas the proportion in the bones was comparatively low (18\%). Schwarz et al. (1994) calculated a comparable distribution for the empty bodies of bulls (German Simmental). For the muscle tissue they found $16 \% \mathrm{Fe}, 58 \% \mathrm{Zn}$ and $12 \% \mathrm{Cu}$, similar to the present study. The elements $\mathrm{Cu}$ and $\mathrm{Mn}$ were also predominantly found in the animal residue.

In the present study, the amounts of the trace elements examined ( $\mathrm{Fe}, \mathrm{Zn}, \mathrm{Cu}$ and $\mathrm{Mn})$, as expected, increased significantly with higher BWs, empty BW as was also found for German Simmental bulls (200-650 kg BW) by Schwarz et al. (1994). The deposition of $\mathrm{Fe}$ and $\mathrm{Cu}$ during the growing period (15-50 kg empty BW) diminished, respectively from 32.9 to $28.0 \mathrm{mg} / \mathrm{kg}$ and from 2.1 to $1.6 \mathrm{mg} / \mathrm{kg}$. However, an increase in the concentration of $\mathrm{Zn}$ and $\mathrm{Mn}$ was revealed (from 25.3 to $28.8 \mathrm{mg} / \mathrm{kg}$ and from 0.51 to $0.79 \mathrm{mg} / \mathrm{kg}$, respectively).

Related to $1000 \mathrm{~g}$ empty BWG, the following concentrations were found for the examined elements: Fe $26.1 \mathrm{mg}, \mathrm{Zn} 30.0 \mathrm{mg}$, Cu $1.41 \mathrm{mg}$ and $\mathrm{Mn} 1.04 \mathrm{mg}$. For 
German Simmental bulls, Schwarz et al. (1994) found higher concentrations (Fe $48 \mathrm{mg}, \mathrm{Zn} 40 \mathrm{mg}$, Cu $2.2 \mathrm{mg}$ and $\mathrm{Mn} 1.3 \mathrm{mg} / \mathrm{kg}$ empty BWG). In the carcass of the lambs (20.8 kg, females), the following concentrations were found for the analysed elements: Fe $28.8 \mathrm{mg}, \mathrm{Zn} 34.8 \mathrm{mg}, \mathrm{Cu}$ $0.88 \mathrm{mg}$ and $\mathrm{Mn} 0.16 \mathrm{mg}$ (Bellof et al., 2007). For comparable lambs $(20.8 \mathrm{~kg}$, females) Suttle (1979) detected in the carcass different concentrations (Fe $61.0 \mathrm{mg}, \mathrm{Zn}$ $25.4 \mathrm{mg}, \mathrm{Cu} 1.00 \mathrm{mg}$ and $\mathrm{Mn} 0.96 \mathrm{mg} / \mathrm{kg}$ fresh weight carcass). Suttle (1979) estimated the following retention (\% intake) of ingested trace elements in lamb carcasses: Fe 1.0, Zn 5.1, Cu 1.7 and $\mathrm{Mn}$ 0.04. In the present trial, a higher retention in the empty body was calculated.

The ARC (1980) states for sheep an average Cu content of $1.15 \mathrm{mg} / \mathrm{kg}$ gain in the carcass. The daily deposition in the carcass ranges from 0.11 to $0.22 \mathrm{mg} \mathrm{Cu}$ per day. For wool, a retention of $0.05 \mathrm{mg} / \mathrm{day}$ is estimated, for the endogenous losses $4 \mu \mathrm{g} / \mathrm{kg} \mathrm{BW}$ and day (ARC, 1980). Thus, the ARC (1980) defines the net requirement as $0.25-0.50 \mathrm{mg} \mathrm{Cu}$ per day for growing lambs (castrated, 20-40 kg BW). In the present study, a mean daily deposition of $0.30 \mathrm{mg} \mathrm{Cu}$ in the empty body was found with a direct feeding influence ('low' $0.20 \mathrm{mg} / \mathrm{day}$, 'high' $0.44 \mathrm{mg} /$ day). It has to be pointed out that a higher content of $\mathrm{Cu}$ in the wool of the Merino Landsheep was detected $(11.6 \mathrm{mg} / \mathrm{kg}$ DM; DM content of the wool 90\%). Phillips et al. (2004) found in the wool of Welsh Mountain ewes 4.8-9.1 mg Cu per $\mathrm{kg}$ DM. The ARC (1980) assumes for wool $5 \mathrm{mg} \mathrm{Cu}$ per $\mathrm{kg} \mathrm{DM}$.

The tissues of growing lambs and cattle contain $24 \mathrm{mg} \mathrm{Zn}$ per kg gain in BW according to the ARC (1980). For wool concentrations of $77-120 \mathrm{mg} \mathrm{Zn}$ per $\mathrm{kg}$ are reported in the literature and thus ARC (1980) assumes on average $115 \mathrm{mg} / \mathrm{kg}$. The endogenous losses are assumed to be $76 \mu \mathrm{g} \mathrm{Zn}$ per kg BW and day. Therefore, the ARC (1980) estimates for growing lambs (castrated, $20-40 \mathrm{~kg} \mathrm{BW}$ ) a net requirement of $6.1-11.2 \mathrm{mg} \mathrm{Zn}$ per day. In our investigations, the average daily deposition of Zn was $6.3 \mathrm{mg}$. However, a daily variation of $4.9-6.9 \mathrm{mg} /$ day was visible as the deposition of $\mathrm{Zn}$ was subject to the significant influence of feeding, BW range and gender. In the wool of the Merino Landsheep lambs, $131 \mathrm{mg} \mathrm{Zn}$ per $\mathrm{kg}$ DM were analysed.

With increasing feeding intensity, the $\mathrm{Zn}$ content per $\mathrm{kg}$ empty BWG diminished significantly whereas the concentration of Cu increased. Schwarz et al. (1994) also found a decreased deposition of $\mathrm{Zn}$ per $\mathrm{kg}$ empty BWG at increased feeding intensity in growing bulls (from $200-350 \mathrm{~kg}$ but not from $350-650 \mathrm{~kg} \mathrm{BW}$ ), whereas for the trace elements $\mathrm{Fe}, \mathrm{Cu}$ and $\mathrm{Mn}$ no direct tendency was seen. In the present trial, the concentration of $\mathrm{Fe}$ and $\mathrm{Mn}$ diminished in tendency. In the literature, no comparable data for the deposition of Fe and Mn could be found for growing lambs. In the recommendations of the ARC (1980) for the supply of lambs, no factorial estimation is derived for these two elements. According to Lassiter and Morton (1968), the concentration of $\mathrm{Mn}$ in the wool seems to be a useful indicator for the assessment of the state of $\mathrm{Mn}$ supply. They found a decline in the concentration of $\mathrm{Mn}$ in the wool from 19 to $6 \mathrm{mg} / \mathrm{kg}$ during a period of $\mathrm{Mn}$ shortage. In our investigations, an average content of $10.3 \mathrm{mg} \mathrm{Mn}$ per $\mathrm{kg} \mathrm{DM}$ in the wool was analysed.

For growing lambs (castrated, 20 and $40 \mathrm{~kg} \mathrm{BW}$ ), the ARC (1980) assumes a true availability for $\mathrm{Cu}$ of 0.22 and 0.09 . Proceeding from the net requirement mentioned above, a daily gross requirement of 1.1 and $5.6 \mathrm{mg} \mathrm{Cu}$ is derived. For lambs of the present trial $(45 \mathrm{~kg} \mathrm{BW}$; deposition: $0.44 \mathrm{mg}$ $\mathrm{Cu}$ per day; endogenous losses: $0.18 \mathrm{mg} \mathrm{Cu}$ per day), the analogous calculation results in a daily gross requirement of $6.9 \mathrm{mg} \mathrm{Cu}$ at high feeding intensity.

For Zn, the ARC (1980) assumes for growing lambs (castrated, 20 and $40 \mathrm{~kg} \mathrm{BW}$ ) a true availability of 0.30 and 0.20 . Proceeding from the net requirement mentioned above, a daily gross requirement of 20 and $56 \mathrm{mg} \mathrm{Zn}$ can be derived. For lambs of the present study $(45 \mathrm{~kg} \mathrm{BW})$, an analogous calculation (deposition: $6.9 \mathrm{mg} \mathrm{Zn}$ per day; endogenous losses: $3.42 \mathrm{mg}$ Cu per day) results in a daily gross requirement of $51.6 \mathrm{mg} \mathrm{Zn}$ at high feeding intensity.

In conclusion, the impact of feeding intensity, gender and final BW on the accretion of the trace elements $\mathrm{Cu}, \mathrm{Fe}, \mathrm{Mn}$ and $\mathrm{Zn}$ in the empty body of lambs of the breed German Merino Landsheep can be summarised as follows. Feeding intensity affects the daily retention of $\mathrm{Fe}, \mathrm{Zn}, \mathrm{Cu}$ and $\mathrm{Mn}$, as well as the deposition of $\mathrm{Zn}$ and Cu per kg empty BWG. Gender has an influence on the daily retention of $\mathrm{Zn}$ and the deposition of $\mathrm{Zn}$ and Fe per $\mathrm{kg}$ empty BWG. Final BW range affects both the daily retention of $\mathrm{Zn}$ and $\mathrm{Mn}$ and the deposition of Zn and Mn per kg empty BWG.

\section{References}

Agricultural Research Council 1980. The nutrient requirements of ruminant livestock. Technical review by an Agricultural Research Council Working Party. CAB, Farnham Royal, UK.

Bellof G and Pallauf J 2004. Deposition of protein fat and energy and utilization of energy for growth in lambs of the breed German Merino landsheep. Animal Science 78, 369-378.

Bellof G, Wolf A, Schuster M and Hollwich W 2003a. Nutrient composition of the muscle, fatty, and bone tissues of carcasses during the development of lambs of the Merino breed. Journal of Animal Physiology and Animal Nutrition 87, 347-358.

Bellof G, Wolf A, Naderer J, Schuster M and Hollwich W 2003b. Investigations on the influence of feeding intensity gender and slaughter weight on fattening and slaughter quality of lambs of the Merino breed. Züchtungskunde 75, 53-68.

Bellof G, Wolf A and Hollwich W 2003c. The influence of gender, slaughter weight and feeding intensity on the tissue composition of Merino lambs. Züchtungskunde 75, 127-143.

Bellof G, Most E and Pallauf J 2007. Concentration of copper, iron, manganese and zinc in muscle, fat and bone tissue of lambs of the breed German Merino Landsheep in the course of the growing period and different feeding intensities. Journal of Animal Physiology and Animal Nutrition 91, 100-108.

Hoffman LC, Muller M, Cloete SWP and Schmidt D 2003. Comparison of six crossbred lamb types: sensory physical and nutritional meat quality characteristics. Meat Science 65, 1265-1274.

Lassiter JW and Morton JD 1968. Effects of low manganese diet on certain ovine characteristics. Journal of Animal Science 27, 776-784.

Lin KC, Cross HR, Johnson HK, Breidenstein BC, Randecker V and Field RA 1989. Mineral composition of lamb carcasses from United States and New Zealand. Meat Science 24, 47-59. 


\section{Bellof and Pallauf}

National Research Council 1985. Nutrient requirements of sheep, sixth revised edition. NRC, National Academy Press, Washington DC.

Phillips CJC, Chiy PC and Omed HM 2004. The effects of cadmium in feed, and its amelioration with zinc, on element balances in sheep. Journal of Animal Science 82, 2489-2502.

Scheper J and Scholz W 1985. Pattern of the cut up of carcasses of cattle, calf, pig and sheep. DLG-Verlag, Frankfurt a. Main.

Schwarz FJ, Heindl U and Kirchgessner M 1994. Contents and deposition of trace elements in tissues and empty body of growing bulls of the genotype Simmental. Journal of Animal Physiology and Nutrition 72, 260-271.
Society of Nutrition Physiology 1995. Evaluation of energy for ruminants Proceedings of the Society of Nutrition Physiology 4, 121-123.

Statistical Analysis Systems Institute 1988. User's guide, release 6.03 edition, SAS Institute Inc., Cary, NC, USA.

Suttle NF 1979. Copper iron, manganese and zinc concentrations in the carcases of lambs and calves and the relationship to trace element requirements for growth. British Journal of Nutrition 42, 89-96.

Wilkinson JM, Hill J and Phillips CJC 2003. The accumulation of potentially toxic metals by grazing ruminants. The Proceedings of the Nutrition Society 62 267-277. 